\title{
Quantification of apolipoprotein E receptors in human brain-derived cell lines by real-time polymerase chain reaction
}

\author{
Shanaka Thilakawardhana ${ }^{\mathrm{a}}$, David M. Everett ${ }^{\mathrm{b}}$, \\ Paul R. Murdock ${ }^{\mathrm{b}}$, Colin Dingwall ${ }^{\mathrm{c}}$, James S. Owen ${ }^{\mathrm{a}, *}$ \\ ${ }^{a}$ Department of Medicine, Royal Free and University College Medical School, Royal Free \\ Campus, University College London, London NW3 2PF, United Kingdom. \\ ${ }^{\mathrm{b}}$ Department of Cellular Genomics, GlaxoSmithKline, Stevenage, SG1 2NY, United Kingdom. \\ c Neurology and Gastrointestinal Centre of Excellence for Drug Discovery, GlaxoSmithKline, \\ Harlow, CM19 5AW, United Kingdom. \\ * Corresponding author. Tel.: +44-20-7433-2853; fax: +44-20-7433-2852 \\ E-mail address: j.owen@rfc.ucl.ac.uk (J.S. Owen) \\ is Parts of this study were presented as a poster at the 4th Neurobiology of Aging conference entitled \\ Developmental Origins of Aging in the Brain and Blood Vessels held in New Orleans, USA, 6-7 \\ November 2003.
}




\begin{abstract}
Apolipoprotein (apo) E4 is a risk factor for Alzheimer's disease, compared to wild-type apoE3. The mechanism(s) is unknown. One possibility, demonstrated in peripheral tissue cell lines, is that apoE stimulates nitric oxide synthase (NOS) via a receptor-dependent signalling pathway and that apoE4 generates inappropriate amounts of NO compared to apoE3. Prior to biochemical investigations, we have quantified the expression of several candidate receptor genes, including low-density lipoprotein (LDL)-receptor family members and scavenger receptor class B, types I and II (SR-BI/II), as well as the three NOS isoenzymes and protein kinase B (Akt), in 38 human cell lines, of which 12 derive from brain. Expression of apoE receptor 2 (apoER2), a known signalling receptor in brain, was readily detected in SH-SY-5Y and CCF-STTG1 cells, common models of neurons and astrocytes, respectively, and was highest in H4 neuroglioma and IMR-32 neuroblastoma cells. Transcripts of the other lipoprotein receptors were widely, but variably, distributed across the different cell types. Of particular note was the predominant expression of SR-BII over SR-BI in many of the brainderived cells. As the C-terminus of SR-BII, like apoER2, contains potential SH3 signalling motifs, we suggest that in brain SR-BII functions as a signal transducer receptor.
\end{abstract}

Keywords: Alzheimer’s disease; apolipoprotein E; nitric oxide; gene expression 


\section{Introduction}

Alzheimer's disease (AD) is the most common neurodegenerative disease and accounts for approximately two-thirds of all cases of dementia [1]. Genetic linkage analysis has identified highly penetrant missense mutations in three genes in familial forms of $\mathrm{AD}$, which directly affect disease pathology hallmarks: the amyloid precursor protein (APP) gene on chromosome 21, presenilin-1 (PS-1) on chromosome 14 and presenilin-2 (PS-2) on chromosome 1 [2-4]. Despite this, $90-95 \%$ of $\mathrm{AD}$ cases are late-onset, occurring sporadically with no observable mutation in the APP or presenilin genes [5,6]. Genes involved in sporadic AD most likely affect disease progression indirectly by modulating one or more metabolic functions in brain relating to normal biosynthesis and homeostasis.

Over 10 years ago, the $\varepsilon 4$ allele of apolipoprotein E (apoE) was identified as a key susceptibility gene in development of late-onset AD [7,8]. Plasma apoE helps regulate cholesterol metabolism by high-affinity receptor binding, which initiates uptake of lipoprotein particles for lysosomal degradation [9]. There are three common apoE alleles, $\varepsilon 2, \varepsilon 3$ and $\varepsilon 4$, which arise from single nucleotide polymorphisms and have frequencies of about 8, 77 and 15 \%, respectively, in Caucasian populations [9]. Each isoform has physiologically distinct receptor binding affinities, reflecting amino acid substitutions, R158C (apoE2) and C112R (apoE4) [9-11]. Brain has the second highest level of apoE mRNA, most being synthesized by astrocytes and microglia [12]. ApoE fulfills several functions in brain, all mediated via receptor-binding: maintenance of cholesterol homeostasis; a targeting protein for local cholesterol redistribution within tissue undergoing repair or re-modelling; an emerging role in developmental processes; and synapse formation [13,14]..

The well-established pathological hallmarks of AD are the deposition of $\beta$-amyloid (A $\beta$ ) in plaques and the accumulation of neurofibrillary tangles, both of which are neurotoxic and contribute to progressive neurodegeneration. The role of apoE in these events is unclear, although it co-localizes with amyloid-rich neuritic plaques in AD brains $[15,16]$ and accumulates in regions of damaged or regenerating nerves, perhaps to scavenge and return released cholesterol for axonal regeneration [17]. Studies in vitro and in transgenic mouse models [18] underline extensive roles for apoE in neurobiology and also reveal isoform differences. In some cases apoE3 fulfills protective functions, in a manner that apoE4 cannot; for example, in binding and stabilising microtubules to inhibit hyperphosphorylation of tau [14,18-20], and in promoting neurite extension which apoE4 impedes [21,22]. In others, apoE4 
is neurotoxic, for example by forming stable complexes with $A \beta[15,16]$ or enhancing fibrillization of $A \beta$ peptides to generate neuritic plaques [18].

In the brain, nitric oxide (NO) is a ubiquitous intercellular messenger that can modulate cerebral blood flow, thrombosis and neurotransmitter release as well as contributing to morphogenesis and synaptic plasticity [23,24]. In excess, however, it is volatile and reacts rapidly with superoxide to form peroxynitrite, a potential mediator of cyto- and neurotoxicity by nitration of amino acids and oxidation of lipids, proteins and DNA [25,26]. We have previously shown in platelets [27] and endothelial cells [28] that binding of apoE by one of its receptors, apoE receptor 2 (apoER2), can initiate a signalling cascade which upregulates endothelial nitric oxide synthase (NOS3) activity and NO production. Furthermore, this effect is isoformdependent with apoE4 releasing much less NO than apoE3 [29].

We hypothesise that apoE will also stimulate NO biosynthesis in neuronal cells and that apoE4 will generate inappropriate amounts compared to apoE3. As a prelude, we have quantified mRNA transcripts of lipoprotein receptors that bind apoE, including apoER2 and scavenger receptor class B, types I and II (SR-BI and SR-BII), using real-time PCR and a diverse panel of human cells, as well as neuronal and astrocytic cell lines. Expression of the three NOS isoenzymes and Akt, the NOS3 regulatory kinase, were also studied. We found that brain cells had the highest levels of apoER2 mRNA and intriguingly that SR-BII predominated over the more common splice variant, SR-BI. The findings also identified suitable cell lines for investigating apoE-dependent biosynthesis of NO in the brain: H4 neuroglioma, IMR-32 neuroblastoma, SH-SY-5Y neuroblastoma and CCF-STTG1 astrocytoma cells.

\section{Materials and Methods}

\subsection{Optimization of PCR conditions}

Prior to quantitative assays, PCR primers and conditions were established by standard PCR using DNA templates from CCF-STTG1 astrocytoma and SH-SY-5Y neuroblastoma cells. These were cultured in RPMI 1640 and Dulbecco's modified Eagle's media (Sigma), respectively, supplemented with $10 \%$ fetal calf serum and $2 \mathrm{mM}$ glutamine (both Life Technologies), at $37^{\circ} \mathrm{C}$ in a $5 \% \mathrm{CO}_{2}$ saturated incubator. Cells were passaged when $70-80 \%$ confluent (usually 2-3 times a week) and DNA was extracted using a commercial kit (Qiagen DNeasy). For RNA preparation, cells were lysed with TRIzol (Life Technologies), extracted with phenol-chloroform and the isolated RNA dissolved in $0.1 \%$ diethyl pyrocarbonate (DEPC) 
water for cDNA synthesis. Reverse transcription was accomplished with oligo-(dT) primers, a mix of dNTPs and the reverse transcriptase enzyme (BioScript, BioGene).

PCR primers were designed using GeneFisher (http://bibiserv.techfak.uni-bielefeld.de/ genefisher/), based on the complete mRNA coding sequences of target genes (GenBank; Table 1), to generate amplicons between 100-200bp; this ensures maximum PCR efficiency when detecting with the intercalating fluorogenic dye, SYBR Green I. Tubes contained 10x PCR buffer $(2.5 \mu \mathrm{l}), 50 \mathrm{mM} \mathrm{MgCl}_{2}(1 \mu \mathrm{l})$, Taq polymerase $(0.125 \mu \mathrm{l}$; Invitrogen), $10 \mathrm{mM} \mathrm{dNTP}$ $(0.125 \mu \mathrm{l}) \mathrm{mix}, 10 \mathrm{mM}$ forward and reverse primers (each $1 \mu \mathrm{l}), 200 \mathrm{ng} / \mu \mathrm{l} \mathrm{cDNA}(2 \mu \mathrm{l})$, and water $(17.25 \mu \mathrm{l})$ and reactions were performed in a standard thermocycler (Biometra TRIOthermoblock), running the program: $94^{\circ} \mathrm{C}$ for $5 \mathrm{~min}, 45$ cycles of $94^{\circ} \mathrm{C}$ for $20 \mathrm{~s}, 60^{\circ} \mathrm{C}$ for $30 \mathrm{~s}$, $72^{\circ} \mathrm{C}$ for $30 \mathrm{~s}$, and a hold of $72^{\circ} \mathrm{C}$ for $10 \mathrm{~min}$. PCR products were visualised under ultra-violet light, following electrophoresis on $2 \%$ agarose gels containing $0.01 \%$ ethidium bromide.

\subsection{Preparation of TaqCell plates}

Analysis of gene expression was performed using a human cell line and primary cell 'TaqCell' masterplate. Briefly, total RNA was extracted from 38 cell lines, including two neuroblastoma cell lines, IMR-32 and SH-SY-5Y, which were also differentiated into more neuron-like morphologies with extended neurites (Table 2). This was achieved by treating IMR-32 cells for 7 days with $1 \mu \mathrm{M}$ retinoic acid, and by supplementing SH-SY-5Y growth medium for 7 days with $1 \mathrm{mM}$ dibutryl cAMP, $100 \mathrm{ng} / \mathrm{ml} 2.5 \mathrm{~S}$ nerve growth factor, $10 \mu \mathrm{g} / \mathrm{ml}$

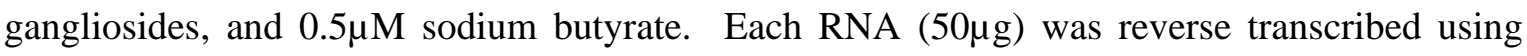
oligo-(dT) 12-18 and SuperScript II reverse transcriptase (Life Technologies) and the cDNA diluted into 96-well plates. The plates with wells containing $5 \mu \mathrm{l}$ of cDNA reverse transcribed from 50ng total RNA from the different cells were then stored at $-80^{\circ} \mathrm{C}$ until use.

\subsection{Quantitative RT-PCR on TaqCell plates}

To each well of cDNA template $(5 \mu \mathrm{l})$, a $20 \mu \mathrm{l}$ reaction mix was added containing $12.5 \mu \mathrm{l}$ '2x PCR mastermix' (comprising optimal amounts of SYBR Green I, $\mathrm{MgCl}_{2}$, dNTP and Taq polymerase), $1 \mu \mathrm{l}$ of $10 \mu \mathrm{M}$ forward primer, $1 \mu \mathrm{l}$ of $10 \mu \mathrm{M}$ reverse primer, and $5.5 \mu \mathrm{l}$ water. PCR assays were performed in duplicate on an ABI 7700 Sequence Detection system (Applied Biosystems) running the cycling conditions: $50^{\circ} \mathrm{C}$ for $2 \mathrm{~min}, 95^{\circ} \mathrm{C}$ for $10 \mathrm{~min}, 45$ cycles of $95^{\circ} \mathrm{C}$ for $15 \mathrm{~s}$, and $60^{\circ} \mathrm{C}$ for $1 \mathrm{~min}$. Immediately following this reaction, melt curve analysis was performed by heating the plate from $60^{\circ} \mathrm{C}$ to $99^{\circ} \mathrm{C}$ and measuring SYBR Green I dissociation from the amplicons. This allowed determination of reaction specificity where a single peak in a 
first derivative plot was indicative of a single amplification product, whereas multiple peaks implied co-amplification of several cDNA species. The copy number of mRNA-derived cDNA in each sample was calculated from a standard curve generated with the use of known amounts of plasmid or genomic DNA. Housekeeping genes, $\beta$-actin and GAPDH, were measured for reference to verify that all samples were integral and of comparable quality. Genomic DNA contamination of the original RNA samples was negligible ( $<10$ copies genomic DNA/50ng RNA), as shown by TaqMan assay of genomic sequence for 10 genes in replicate samples taken through the reverse transcription procedure, but with the reverse transcriptase omitted.

\section{Results}

\subsection{Standard PCR assay to test primers}

Before primers were used in TaqCell plate assays, it was important to verify that each chosen pair would selectively amplify their target under identical conditions. This was done using cDNA templates from CCF-STTG1 and SH-SY-5Y cells and performing reactions in a standard thermocycler, in some cases evaluating several primer pairs for each target. The final ones selected all showed clear, single-band products by electrophoretic gel analysis for each lipoprotein receptor (Fig. 1A), and also for the NOS isoforms and PKB/Akt (Fig. 1B), without obvious contamination by artefactual bands, mispriming, or primer-dimer complexes. A reaction using validated TaqCell primers for the housekeeping gene, $\beta$-actin, as a positive control, also gave a single band (Fig, 1B).

\subsection{Expression of LDL-receptor family members}

Expression of the low-density lipoprotein receptor (LDL-r) was observed in all cell lines (Fig. 2A). With few exceptions, copies of mRNA detected exceeded 100,000/50ng total RNA across the whole plate, with UT7-Epo cells having the highest level. Expression levels in the brain-derived cells did not obviously differ from the other cell lines. The VLDL-r showed a distinct expression profile (Fig. 2B), with large differences in mRNA levels between cell types. The highest levels of gene expression were generally in cells from the vessel wall, while brainderived cells also displayed strong expression, both in astrocytoma and neuroblastoma cells. In the two differentiated neuroblastoma cells, expression of the VLDL-r was upregulated, 2.9times in IMR-32 and 1.5-times in SH-SY-5Y. Similar upregulation was also seen in AOSMC smooth muscle cells (2.9-times higher) following serum stimulation. 
Although all cell lines expressed LRP, mRNA levels across the TaqCell plate were highly cell-dependent, with vessel wall-derived cell lines and macrophages giving the highest copy numbers (Fig. 2C). As with VLDL-r expression, there was upregulation of LRP in the differentiated brain-derived cell lines, markedly so for IMR-32 cells (32-times), while expression in SH-SY-5Y cells doubled. ApoER2 mRNA was detected at a lower level than the other LDL-r gene family members (Fig. 2D). However, a survey across the plate revealed that both astrocytoma and neuroblastoma cell lines displayed high apoER2 expression, relative to the other cell types, with the greatest level found in H4 neuroglioma cells. Differentiated IMR-32 cells showed a 30\% rise in apoER2 mRNA, consistent with increased expression of LDL-r and VLDL-r, whereas this was not seen in SH-SY-5Y cells, which expressed 55\% less apoER2 mRNA than undifferentiated cells.

\subsection{Expression of HDL receptors, SR-BI and SR-BII}

Expression of the high-density lipoprotein (HDL) receptors, SR-BI (Fig. 3A) and SR-BII (Fig. 3B) was readily apparent in nearly all cell types on the TaqCell plate. For SR-BI, the level of mRNA was generally much higher in the astrocytoma cell lines than in the neuroblastoma lines, although H4 neuroglioma cells were an exception. This preferential expression in astrocytoma lines was less obvious when levels of SR-BII mRNA were analysed, as IMR-32, SH-SY-5Y and NT-2 neuroblastoma cells showed strong expression. SR-BII, the splice variant of SR-BI, is produced by exon-skipping to give a mRNA transcript that differs by 129bp. The frequency of such an event is rare, making SR-BI the predominantly expressed variant. This is consistent with our TaqCell data, which reveal greater expression of SR-BI than SR-BII in virtually all non-brain cell lines. Interestingly, in many brain-derived cells SR-BII predominated as clearly shown when the SR-BII:SR-BI ratio was calculated (Fig. 3C). However, this preferential expression of SR-BII was confined to neuroblastoma cells, as each of the four astrocytoma cell lines had higher copy numbers of SR-BI mRNA than SR-BII mRNA. In three cells, differentiated IMR-32, SK-N-SH and NT-2 precursor cells, there was over 30times greater expression of SR-BII than SR-BI. These findings contrast with previous reports of the proportional distribution of these receptors in other tissues [30], and with our present survey across a wide range of cell types.

\subsection{Expression of NOS isoforms and PKB/Akt}

The three NOS isoform mRNAs were detected at lower levels than those of the lipoprotein receptors, rarely exceeding 4,000 mRNA copies detected/50ng total RNA. NOS1 mRNA was 
detected at the lowest level with several of the brain-derived cell lines showing no expression (Fig. 4A). SH-SY-5Y cells gave the highest level of 430 mRNA copies detected (and was also highest across the whole plate; data not shown), although upon differentiation there was a dramatic decrease in NOS1 mRNA expression. NOS2 mRNA was detected in all the brainderived cells with half showing a 'basal' expression level of $\sim 400$ mRNA copies detected/ 50ng total RNA (Fig. 4B), which was similar to that detected in the other cell types on the plate (data not shown). NOS3 mRNA was also readily detected and ten of the twelve brain-derived cells gave a consistent expression level of 1500-3000 mRNA copies detected/ 50ng total RNA. The two exceptions, C13 and differentiated IMR-32 cells, gave levels of 4,200 and 8,000 mRNA copies detected/ 50ng total RNA, respectively (Fig. 4C). For both NOS2 and NOS3, the two differentiated cell lines showed similar changes in mRNA expression compared to their undifferentiated counterparts. In the case of IMR-32 cells differentiation produced 3-4-fold increases in NOS2 and NOS3 expression, while in SH-SY-5Y cells the change was in the opposite direction with differentiation leading to halving of mRNA copy numbers (Fig. 4B,C).

Expression of Akt mRNA (Fig. 4D) was usually high across all cell types on the TaqCell plate, many cell lines having an expression level fluctuating marginally around the mean of 100,000 mRNA copies detected/ 50ng total RNA. Most brain-derived cells also showed good expression of Akt mRNA, with values similar to other cell lines and in some cases exceeding them. The three highest expressing lines were the 1321N1, C13 and CCF-STG1 astrocytoma cells, which each gave levels of 120,000 mRNA copies detected/ 50ng total RNA. Differentiation of IMR-32 and SH-SY-5Y cell lines produced $170 \%$ and $40 \%$ increases in expression, respectively, to about 80,000 mRNA copies detected/ 50ng total RNA compared to the undifferentiated forms.

\section{Discussion}

This study has used quantitative RT-PCR to measure mRNA expression levels of a range of genes involved in apoE metabolism and NO biosynthesis, focusing on genes encoding receptors capable of binding apoE-containing lipoproteins. To our knowledge, this is the first such survey of gene expression, covering an extensive and diverse range of human tissue cell lines, including those derived from brain-cells. The generic probe, SYBR Green I, which intercalates into the double-strand DNA amplicons, was used to monitor PCR reactions rather than a synthetic oligonucleotide-based reagent specific for each gene. However, all assays were sensitive and specific, as judged by rigorous electrophoretic and melt curve analyses of primer pairs prior to their use in TaqCell plates. Nevertheless, individual assays give only information 
on mRNA levels; in particular, whether a gene is expressed by a cell line, and its copy number relative to other cell lines and to other genes investigated. It does not follow, however, that mRNA levels are a true reflection of protein expression; an important consideration when evaluating the data and for future studies.

The LDL-r is the archetypical cell-surface receptor mediating endocytosis of its ligand, in this case apoE or apoB100 which deliver lipid nutrients. It is expressed in virtually all cells and tissues at variable levels, which our findings in TaqCell plates confirm. The LDL-r is widely expressed in brain and, as apoB100 and LDL are absent from cerebrospinal fluid [31], it appears that their role in lipid transport and cholesterol homeostasis is fulfilled by apoE [17,31]. Structurally, the VLDL-r and apoER2 are very similar to the LDL-r and to each other; both bind apoE3 and apoE4 with similar affinities [32,33]. The VLDL-r is abundantly expressed in heart and skeletal muscle and adipose, which all actively metabolize fatty acids acquired from triglyceride-rich lipoproteins [34,35], whereas apoER2 is absent from these tissues and reported to predominate in brain, with a widespread distribution [36]. Subsequent immunohistochemical studies also revealed VLDL-r expression in brain, including hippocampal cortical neurons and microglia, particularly those associated with senile plaques [37,38]. Data from our TaqCell plates were consistent with this tissue distribution, including the strong expression of VLDL-r and apoER2 across most of the brain-derived cell lines.

Studies in mice that lack both VLDL-r and apoER2 have highlighted key roles for these receptors in neuronal migration and development of the nervous system. The double knockout mice have marked behavioural and neuroanatomical features, which includes cerebellar dysplasia and severe ataxia, and disruption of cortical layering. This phenotype is identical to the mutant mouse strains, Scrambler and Reeler, which have dysfunctional forms of the intracellular adaptor protein, Disabled-1 (Dab-1) [39], and the large secreted signalling glycoprotein, Reelin [39,40], respectively. Genetic and biochemical studies now group these disparate proteins into a common signalling pathway in which Reelin binds with high-affinity to VLDL-r or apoER2, an interaction which promotes Dab-1 binding to the cytoplasmic NPxY motifs of both receptors [14]. This initial Reelin signal stimulates tyrosine phosphorylation of Dab-1, which in turn can then activate a variety of downstream signalling components $[14,41,42]$.

At $600-\mathrm{kDa}$, LRP is much larger than the other LDL-r family members studied and contains two NPxY motifs and one tyrosine-based YxxL motif. It has broad binding specificity with over 30 different ligands many of which are internalized, interestingly via the alternative endocytic signalling motif, YxxL, which dominates [43]. In addition, several adaptor and scaffold proteins, including Dab-1, potentially bind the cytoplasmic NPxY motifs of LRP and, 
although biochemical and physiological details are incomplete, numerous regulatory functions are suggested, including mitogen-activated protein (MAP) kinase signalling, ion channel function, microtubular transport, and axon guidance [41,44,45]. Genetic association studies suggest a direct link between LRP and AD, as the C766T polymorphism in exon 3 of LRP is under-represented [46]. However, although brains of AD patients with CT or TT genotypes contain higher levels of LRP [47] and circumstantial evidence suggests that LRP promotes Aß clearance [48], the relationship remains controversial [49]. Similarly, polymorphisms in the VLDL-r [37,38] and apoER2 [50] have been identified and are suggested to be risk factors for $\mathrm{AD}$, but further studies are needed to verify these possibilities.

Scavenger receptor class B, type I mediates the selective uptake of cholesteryl esters from HDL without degrading the particles. It was the first authentic HDL binding protein to be characterized [51], although other ligands including apoE are now recognized [52]. A splice variant, termed SR-BII, was subsequently identified; this results from exon 12 skipping [30,53] to produce a receptor with a different C-terminal cytoplasmic tail, but identical extracellular binding region, to that of SR-BI. This implies differential functions; for example, the interaction between C-terminal SR-BI and PDZK1, a scaffolding protein [54], would not occur with SRBII. On the other hand, cytoplasmic SR-BII contains six PxxP motifs, two being conserved in rat, mouse and hamster, which are potential ligands for tyrosine kinases or adaptor proteins with Src homology 3 (SH3) domains [30]. The presence of these motifs, which are also seen in cytoplasmic apoER2 [55], suggests that SR-BII may initiate signalling pathways that cannot be mediated by SR-BI; an exciting possibility given the preferential expression of SR-BII in many brain-derived cell lines (Fig. 3C).

Copy numbers of NOS mRNA transcripts were generally low in all cells, although presumably adequate to maintain basal NO levels that are biologically functional without being cyto- or neurotoxic. Under normal physiological conditions, relatively little NO is synthesized and it appears that cells only transcribe NOS genes at low levels. Indeed, production of NO commonly reflects the catalytic activity of the enzyme, which depends on intracellular $\mathrm{Ca}^{2+}$ concentrations, the availability of substrates or co-factors, and an array of heterologous protein partners [56]. Both NOS1 and NOS3 are constitutively transcribed, whereas NOS2 expression is induced by cytokines, such as IFN- $\gamma$. Recently, phosphorylation at $\operatorname{Ser}^{1177}$ has emerged as a key regulatory mechanism of NOS3 activity, most likely because the enzyme can then bind calcium-activated calmodulin at low calcium concentration. The phosphorylation of NOS3 can be mediated by protein kinase A (PKA) or AMP kinase, but is accomplished more frequently by protein kinase B (PKB; usually termed Akt), which also helps regulate apoptosis and cellular proliferation and is itself phosphorylated and activated by phosphatidylinositol (PI) 3-kinase 
[57]. Here, we have measured NOS and Akt mRNA transcripts in each cell line, which as discussed above may not accurately reflect protein levels. Thus, although our data identify cells that express the three isoenzymes and the key activator of NOS3, the measurement of NOS proteins and a functional assessment of NO synthesis must await additional investigations.

In summary, our study has demonstrated that receptors recognizing apoE are widely expressed in brain-derived cell lines. Of note were the strong expression of apoER2 in these cells, which we have previously implicated in apoE-mediated stimulation of NO release in platelets and endothelium, and the preferential expression of SR-BII, which is rich in cytoplasmic SH3 motifs, over the normal splice variant, SR-BI. Our findings also identified H4 neuroglioma, IMR-32 neuroblastoma, SH-SY-5Y neuroblastoma and CCF-STTG1 astrocytoma cells as being suitable human brain cells for investigating apoE-dependent biosynthesis of NO and whether apoE4 and apoE3 have differential effects.

\section{Acknowledgements}

This study was supported by a PhD studentship from the British Biotechnology and Biological Sciences Research Council (BBSRC) in conjunction with GlaxoSmithKline. The authors would like to thank Dr Kong B Tan, Dr Karen L Philpott and Mr Gary B. T. Moore for their assistance with TaqCell preparation. 


\section{References}

[1] Nussbaum RL, Ellis CE. (2003) Alzheimer's disease and Parkinson's disease. N Engl J Med 2003; 48:1356-64.

[2] Myers AJ, Goate AM. The genetics of late-onset Alzheimer's disease. Curr Opin Neurol 2001;14:433-40.

[3] Li YJ, Scott WK, Hedges DJ, Zhang F, Gaskell PC, Nance MA, et al. Age at onset in two common neurodegenerative diseases is genetically controlled. Am J Hum Genet 2002;70:985-93.

[4] Suh YH, Checler F. Amyloid precursor protein, presenilins, and alpha-synuclein: molecular pathogenesis and pharmacological applications in Alzheimer's disease. Pharmacol Rev 2002;54:469-525.

[5] Meyer MR, Tschanz JT, Norton MC, Welsh-Bohmer KA, Steffens DC, Wyse BW, et al. APOE genotype predicts when - not whether - one is predisposed to develop Alzheimer disease. Nat Genet 1998;19:321-2

[6] Ritchie K, Lovestone S. The dementias. Lancet 2002;360:1759-66.

[7] Corder EH, Saunders AM, Strittmatter WJ, Schmechel DE, Gaskell PC, Small GW, et al. Gene dose of apolipoprotein E type 4 allele and the risk of Alzheimer's disease in late onset families. Science 1993; 261:921-3.

[8] Corder EH, Lannfelt L, Bogdanovic N, Fratiglioni L, Mori H. The role of APOE polymorphisms in late-onset dementias. Cell Mol Life Sci 1998;54:928-34.

[9] Weisgraber KH. Apolipoprotein E: structure-function relationships. Adv Protein Chem 1994;45:249-302.

[10] Mahley RW, Huang Y. Apolipoprotein E: from atherosclerosis to Alzheimer's disease and beyond. Curr Opin Lipidol 1999;10:207-17.

[11] Mahley RW, Huang Y, Rall SC Jr. Pathogenesis of type III hyperlipoproteinemia (dysbetalipoproteinemia). Questions, quandaries, and paradoxes. J Lipid Res 1999;40:1933-49.

[12] Strittmatter WJ, Bova Hill C. Molecular biology of apolipoprotein E. Curr Opin Lipidol 2002;13:119-23.

[13] Beffert U, Danik M, Krzywkowski P, Ramassamy C, Berrada F, Poirier J. The neurobiology of apolipoproteins and their receptors in the CNS and Alzheimer's disease. Brain Res Rev 1998;27:119-42.

[14] Beffert U, Stolt PC, Herz J. Functions of lipoprotein receptors in neurons. J Lipid Res 2004;45:4039.

[15] Weisgraber KH, Mahley RW. Human apolipoprotein E: the Alzheimer's disease connection. FASEB J 1996;10:1485-94. 
[16] Gearing M, Schneider JA, Robbins RS, Hollister RD, Mori H, Games D, et al. Regional variation in the distribution of apolipoprotein E and A beta in Alzheimer's disease. J Neuropathol Exp Neurol 1995;54:833-41.

[17] Vance JE, Campenot RB, Vance DE. The synthesis and transport of lipids for axonal growth and nerve regeneration. Biochim Biophys Acta 2000;1486:84-96.

[18] Bales KR, Dodart JC, DeMattos RB, Holtzman DM, Paul SM Apolipoprotein E, amyloid, and Alzheimer disease. Mol Interv 2002;2:363-75.

[19] Strittmatter WJ, Saunders AM, Goedert M, Weisgraber KH, Dong LM, Jakes R, et al. Isoformspecific interactions of apolipoprotein E with microtubule-associated protein tau: implications for Alzheimer disease. Proc Natl Acad Sci USA 1994;91: 11183-6.

[20] Scott BL, Welch K, deSerrano V, Moss NC, Roses AD, Strittmatter WJ. Human apolipoprotein E accelerates microtubule polymerization in vitro. Neurosci Lett 1998;245:105-8

[21] Bellosta S, Nathan BP, Orth M, Dong LM, Mahley RW, Pitas RE. Stable expression and secretion of apolipoproteins E3 and E4 in mouse neuroblastoma cells produces differential effects on neurite outgrowth. J Biol Chem 1995;270: 27063-71.

[22] Teter B, Xu PT, Gilbert JR, Roses AD, Galasko D, Cole GM. Defective neuronal sprouting by human apolipoprotein E4 is a gain-of-negative function. J Neurosci Res 2002;68:331-6.

[23] Law A, Gauthier S, Quirion R. Say NO to Alzheimer's disease: the putative links between nitric oxide and dementia of the Alzheimer's type. Brain Res Rev 2001;35:73-96.

[24] Murphy S. Production of nitric oxide by glial cells: regulation and potential roles in the CNS. Glia. 2000;29:1-13.

[25] Brown GC. Nitric oxide inhibition of cytochrome oxidase and mitochondrial respiration: implications for inflammatory, neurodegenerative and ischaemic pathologies. Mol Cell Biochem 1997;174:189-92.

[26] Wiesinger H. Arginine metabolism and the synthesis of nitric oxide in the nervous system. Prog Neurobio 2001;64:365-91

[27] Riddell DR, Graham A, Owen JS. Apolipoprotein E inhibits platelet aggregation through the Larginine:nitric oxide pathway. Implications for vascular disease. J Biol Chem 1997;272:89-95.

[28] Stannard AK, Riddell DR, Sacre SM, Tagalakis AD, Langer C, von Eckardstein A, et al. Cellderived apolipoprotein E (ApoE) particles inhibit vascular cell adhesion molecule-1 (VCAM-1) expression in human endothelial cells. J Biol Chem 2001;276:46011-6.

[29] Sacre SM, Stannard AK, Owen JS. Apolipoprotein E (apoE) isoforms differentially induce nitric oxide production in endothelial cells. FEBS Lett 2003;540:181-7.

[30] Mulcahy JV, Riddell DR, Owen JS. Human scavenger receptor class B type II (SR-BII) and cellular cholesterol efflux. Biochem J 2004;377:741-7. 
[31] Guyton JR, Miller SE, Martin ME, Khan WA, Roses AD, Strittmatter WJ. Novel large apolipoprotein E-containing lipoproteins of density 1.006-1.060 g/ml in human cerebrospinal fluid. J Neurochem 1998;70:1235-40.

[32] Takahashi S, Oida K, Ookubo M, Suzuki J, Kohno M, Murase T, et al. Very low density lipoprotein receptor binds apolipoprotein E2/2 as well as apolipoprotein E3/3. FEBS Lett 1996;386:197-200.

[33] Li X, Kypreos K, Zanni EE, Zannis V. Domains of apoE required for binding to apoE receptor 2 and to phospholipids: implications for the functions of apoE in the brain. Biochemistry 2003;42:10406-17.

[34] Webb JC, Patel DD, Jones MD, Knight BL, Soutar AK. Characterization and tissue-specific expression of the human 'very low density lipoprotein (VLDL) receptor' mRNA. Hum Mol Genet 1994;3:531-7.

[35] Strickland DK, Gonias SL, Argraves WS. Diverse roles for the LDL receptor family. Trends Endocrinol Metab 2002;13:66-74.

[36] Kim DH, Iijima H, Goto K, Sakai J, Ishii H, Kim HJ, et al. Human apolipoprotein E receptor 2. A novel lipoprotein receptor of the low density lipoprotein receptor family predominantly expressed in brain. J Biol Chem 1996;271:8373-80.

[37] Okuizumi K, Onodera O, Namba Y, Ikeda K, Yamamoto T, Seki K, et al. Genetic association of the very low density lipoprotein (VLDL) receptor gene with sporadic Alzheimer's disease. Nat Genet 1995;11:207-9.

[38] Helbecque N, Amouyel P. Very low density lipoprotein receptor in Alzheimer disease. Microsc Res Tech 2000;50:273-7.

[39] Weiss KH, Johanssen C, Tielsch A, Herz J, Deller T, Frotscher M, et al. Malformation of the radial glial scaffold in the dentate gyrus of reeler mice, scrambler mice, and ApoER2/VLDLR-deficient mice. J Comp Neurol 2003;460:56-65.

[40] Tissir F, Goffinet AM. Reelin and brain development. Nature Rev Neurosci 2003;4:496-505.

[41] Herz J, Bock HH. Lipoprotein receptors in the nervous system. Annu Rev Biochem 2002;71:40534.

[42] Benhayon D, Magdaleno S, Curran T. Binding of purified Reelin to ApoER2 and VLDLR mediates tyrosine phosphorylation of Disabled-1. Brain Res Mol Brain Res 2003;112:33-45.

[43] Li Y, Marzolo MP, van Kerkhof P, Strous GJ, Bu G. The YXXL motif, but not the two NPXY motifs, serves as the dominant endocytosis signal for low density lipoprotein receptor-related protein. J Biol Chem 2000;275:17187-94.

[44] Herz J, Strickland DK. LRP: a multifunctional scavenger and signaling receptor. J Clin Invest 2001;108:779-84.

[45] Schneider WJ, Nimpf J. LDL receptor relatives at the crossroad of endocytosis and signaling. Cell Mol Life Sci 2003;60:892-903. 
[46] Sanchez-Guerra M, Combarros O, Infante J, Llorca J, Berciano J, Fontalba A, et al.. Case-control study and meta-analysis of low density lipoprotein receptor-related protein gene exon 3 polymorphism in Alzheimer's disease. Neurosci Lett 2001;316:17-20.

[47] Kang DE, Pietrzik CU, Baum L, Chevallier N, Merriam DE, Kounnas MZ, et al. Modulation of amyloid beta-protein clearance and Alzheimer's disease susceptibility by the LDL receptor-related protein pathway. J Clin Invest 2000;106:1159-66.

[48] Ulery PG, Strickland DK. LRP in Alzheimer's disease: friend or foe? J Clin Invest 2000;106:10779.

[49] Causevic M, Ramoz N, Haroutunian V, Davis KL, Buxbaum JD. Lack of association between the levels of the low-density lipoprotein receptor-related protein (LRP) and either Alzheimer dementia or LRP exon 3 genotype. J Neuropathol Exp Neurol 2003;62:999-1005.

[50] Ma SL, Ng HK, Baum L, Pang JC, Chiu HF, Woo J, et al. Low-density lipoprotein receptor-related protein 8 (apolipoprotein E receptor 2) gene polymorphisms in Alzheimer's disease. Neurosci Lett 2002;332:216-8.

[51] Acton S, Rigotti A, Landschulz KT, Xu S, Hobbs HH, Krieger M. Identification of scavenger receptor SR-BI as a high density lipoprotein receptor. Science 1996;271:518-520.

[52] Bultel-Brienne S, Lestavel S, Pilon A, Laffont I, Tailleux A, Fruchart JC, et al. Lipid free apolipoprotein E binds to the class B Type I scavenger receptor I (SR-BI) and enhances cholesteryl ester uptake from lipoproteins. J Biol Chem 2002;277:36092-9.

[53] Webb NR, Connell PM, Graf GA, Smart EJ, de Villiers WJ, de Beer FC, et al. SR-BII, an isoform of the scavenger receptor BI containing an alternate cytoplasmic tail, mediates lipid transfer between high density lipoprotein and cells. J Biol Chem 1998;273:15241-8.

[54] Silver DL. A carboxyl-terminal PDZ-interacting domain of scavenger receptor B, type I is essential for cell surface expression in liver. J Biol Chem 2002;277:34042-7.

[55] Riddell DR, Vinogradov DV, Stannard AK, Chadwick N, Owen JS. Identification and characterization of LRP8 (apoER2) in human blood platelets. J Lipid Res 1999;40:1925-30.

[56] Kone BC, Kuncewicz T, Wang W, Yu Z-Y. Protein interactions with nitric oxide synthases: controlling the right time, the right place, and the right amount of nitric oxide. Am J Physiol Renal Physiol 2003;285:F178-90.

[57] Scheid MP, Woodgett JR. Unravelling the activation mechanisms of protein kinase B/Akt. FEBS Lett 2003;546:108-12. 
Table 1

Primer sequences selected for TaqCell plate assays and the expected PCR product sizes.

\begin{tabular}{|c|c|c|c|c|}
\hline Gene & $\begin{array}{c}\text { GenBank } \\
\text { accession } \\
\text { number }\end{array}$ & Primer & Sequence $5^{\prime}-3^{\prime}$ & $\begin{array}{l}\text { Product } \\
\text { size }\end{array}$ \\
\hline LDL-r & NM00527 & $\begin{array}{l}\text { Forward } \\
\text { Reverse }\end{array}$ & $\begin{array}{l}\text { GCGAAGATGCGAAGATATCGATG } \\
\text { CCGGTTGGTGAAGAAGAGGTAG }\end{array}$ & 172bp \\
\hline VLDL-r & NM003383 & $\begin{array}{l}\text { Forward } \\
\text { Reverse }\end{array}$ & $\begin{array}{l}\text { CTGCAGCCATTGCTGTTGATTGG } \\
\text { CCAGTAAACAAAGCCAGACAGTG }\end{array}$ & 173bp \\
\hline LRP & NM002332 & $\begin{array}{l}\text { Forward } \\
\text { Reverse }\end{array}$ & $\begin{array}{l}\text { GATCCCAATGACAAGTCAGATGC } \\
\text { ATGCCATTGGTCACCACGTCTTC }\end{array}$ & 173bp \\
\hline ApoER2 & D50678 & $\begin{array}{l}\text { Forward } \\
\text { Reverse }\end{array}$ & $\begin{array}{l}\text { GCGGAACTATTCACGCCTCA } \\
\text { TGCGATTGGTGGCAACTTC }\end{array}$ & 74bp \\
\hline SR-BI & Z22555 & $\begin{array}{l}\text { Forward } \\
\text { Reverse }\end{array}$ & $\begin{array}{l}\text { GGTCCCTGTCATCTGCCAA } \\
\text { CTCCTTATCCTTTGAGCCCTTT }\end{array}$ & 85bp \\
\hline SR-BII & Z22555 & $\begin{array}{l}\text { Forward } \\
\text { Reverse }\end{array}$ & $\begin{array}{l}\text { TCCTGAGGACACCGTGAGC } \\
\text { GAGGCTCAGGCTGTGG }\end{array}$ & 123bp \\
\hline NOS1 & AH005382 & $\begin{array}{l}\text { Forward } \\
\text { Reverse }\end{array}$ & $\begin{array}{l}\text { TGCTGCGATGCAATGCTT } \\
\text { GACGGCCATGTTCCAGT }\end{array}$ & 117bp \\
\hline NOS2 & NM153292 & $\begin{array}{l}\text { Forward } \\
\text { Reverse }\end{array}$ & $\begin{array}{l}\text { ACAAGCCTACCCCTCCAGAT } \\
\text { CCTGGCCAGATGTTCCTCTA }\end{array}$ & 104bp \\
\hline NOS3 & A519768 & $\begin{array}{l}\text { Forward } \\
\text { Reverse }\end{array}$ & $\begin{array}{l}\text { CCTGGAGAATGAGCAGAAGG } \\
\text { GTTGACCATCTCCTGATGGAA }\end{array}$ & 109bp \\
\hline PKB/Akt & M95936 & $\begin{array}{l}\text { Forward } \\
\text { Reverse }\end{array}$ & $\begin{array}{l}\text { TCACTGCGCTGAAGTATGCCTTC } \\
\text { CGCGAGTGCAAGTACTCAAGAG }\end{array}$ & 171bp \\
\hline$\beta$-Actin & X00351 & $\begin{array}{l}\text { Forward } \\
\text { Reverse }\end{array}$ & $\begin{array}{l}\text { AGGCTACGAGCTGCCTGACG } \\
\text { GTAGTTTCGTGGATGCCACAGGACT }\end{array}$ & 215bp \\
\hline
\end{tabular}




\section{Table 2}

Human primary cells and cell lines present on the TaqCell plate. Brain-derived cell lines are highlighted.

\begin{tabular}{|c|c|}
\hline Cells, Cell Lines and Tissue Source & Description \\
\hline $\begin{array}{l}\text { Vessel Wall } \\
\text { AOSMC- (unstimulated) } \\
\text { AOSMC+ (serum stimulated) } \\
\text { HCAEC } \\
\text { HCA-SMC } \\
\text { Bladder-SMC }\end{array}$ & $\begin{array}{l}\text { Aortic smooth muscle cells } \\
\text { Aortic smooth muscle cells } \\
\text { Human coronary artery endothelial cells } \\
\text { Human coronary artery smooth muscle cells } \\
\text { Bladder smooth muscle cells }\end{array}$ \\
\hline $\begin{array}{l}\text { Liver } \\
\text { Chang } \\
\text { HepG2 } \\
\text { WRL68 }\end{array}$ & $\begin{array}{l}\text { Liver cells } \\
\text { Hepatocyte carcinoma } \\
\text { Liver carcinoma }\end{array}$ \\
\hline $\begin{array}{l}\text { Blood } \\
\text { Lymphocytes } \\
\text { Macrophages (monocyte-derived) } \\
\text { THP-1 (unstimulated) } \\
\text { Neutrophils } \\
\text { CMK-86 } \\
\text { M-07e } \\
\text { UT7-Epo }\end{array}$ & $\begin{array}{l}\text { Primary culture } \\
\text { Primary culture } \\
\text { Monocytic } \\
\text { Primary culture } \\
\text { Megakaryocyte } \\
\text { Megakaryocyte } \\
\text { Megakaryocyte }\end{array}$ \\
\hline $\begin{array}{l}\text { Bone/Cartilage } \\
\text { C20A4 } \\
\text { HOS } \\
\text { MG63 } \\
\text { SAOS2 } \\
\text { HAC60 }\end{array}$ & $\begin{array}{l}\text { Chondrocytes } \\
\text { Osteosarcoma cells } \\
\text { Osteosarcoma cells } \\
\text { Osteosarcoma cells } \\
\text { Articular chondrocytes }\end{array}$ \\
\hline $\begin{array}{l}\text { Astrocytoma/glia } \\
1321 \mathrm{~N} 1 \\
\text { C13 } \\
\text { Hs-683 } \\
\text { CCF-STTG1 } \\
\end{array}$ & $\begin{array}{l}\text { Brain astrocytoma } \\
\text { Immortalised immature microglial cell } \\
\text { Glioma } \\
\text { Astrocytoma }\end{array}$ \\
\hline 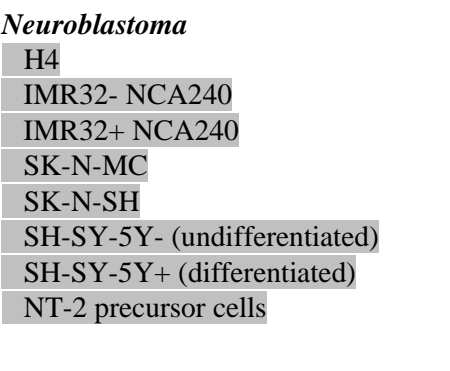 & $\begin{array}{l}\text { Brain neuroglioma } \\
\text { Neuroblastoma } \\
\text { Neuroblastoma } \\
\text { Neuroblastoma } \\
\text { Neuroblastoma } \\
\text { Neuroblastoma } \\
\text { Neuroblastoma } \\
\text { Ntera/D1 cell line, derived from a human teratocarcinoma, represents a } \\
\text { committed neuronal precursor stage of differentiation }\end{array}$ \\
\hline $\begin{array}{l}\text { Others } \\
\text { Prostate SMC } \\
\text { HK-2 }\end{array}$ & $\begin{array}{l}\text { Prostate smooth muscle cells, primary, p3 } \\
\text { Kidney, cortex, proximal tube, HPV-16 transformed }\end{array}$ \\
\hline $\begin{array}{l}\text { Parental Background Cells } \\
\text { HEK } 293 \\
\text { HeLa } \\
\text { COS-1 }\end{array}$ & $\begin{array}{l}\text { Embryonic kidney } \\
\text { Epithelilial cervical adenocarcinoma } \\
\text { Kidney fibroblast-like, derived from CV-1 cells, transformed with origin- } \\
\text { defective mutant of SV- } 40 \text { coding for WT T-antigen } \\
\text { Foetal lung fibroblast (female) }\end{array}$ \\
\hline
\end{tabular}




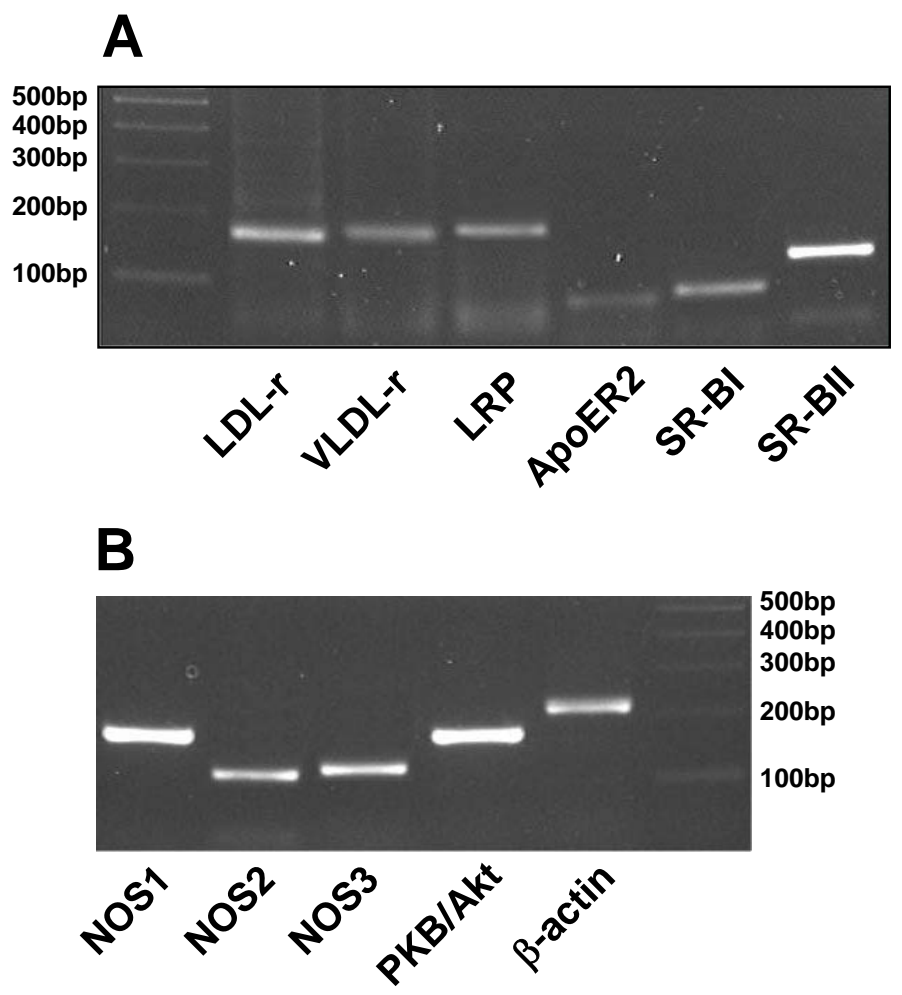

Fig. 1. PCR products of genes investigated. (A) Lipoprotein receptors - LDL-r, VLDL-r, LRP, apoER2, SR-BI, and SR-BII. (B) Proteins involved in NO biosynthesis - NOS1, NOS2, NOS3, and $\mathrm{PKB} /$ Akt. Reactions were performed in a standard thermocycler and the products separated by $2 \%$ agarose gel electrophoresis. 

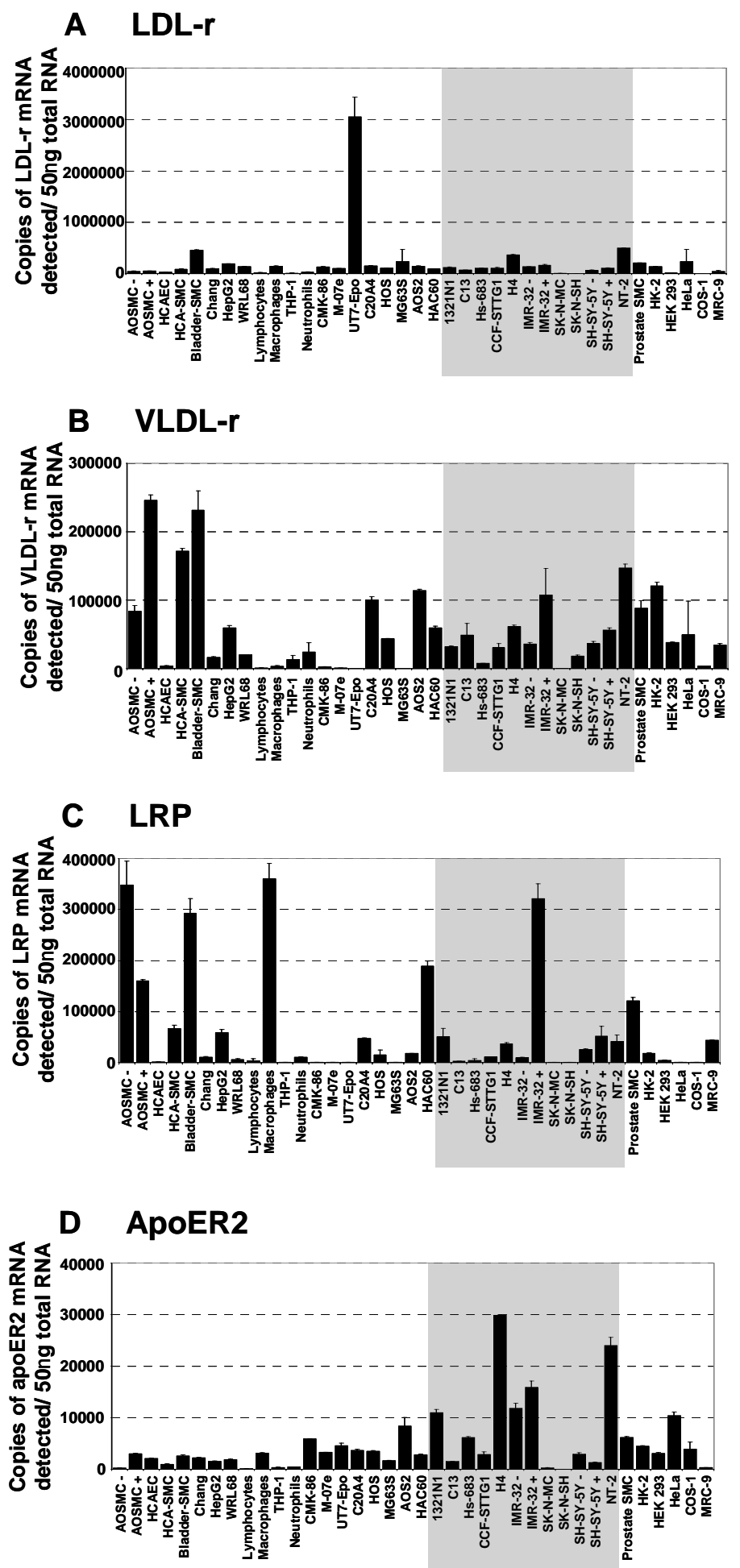

Fig. 2. Expression of LDL-receptor gene family members by TaqCell plate assay. Levels of mRNA were measured in 38 human cell lines and primary cells for (A) LDL-r, (B) VLDL-r, (C) LRP and (D) apoER2. Brain-derived cell lines are highlighted. Data shown are the mean of a duplicate measurement ( \pm S.E.) of mRNA copy numbers in 50ng of reverse transcribed total RNA from the same batch of cells. Note that the scaling on the Y-axis of each graph differs. 

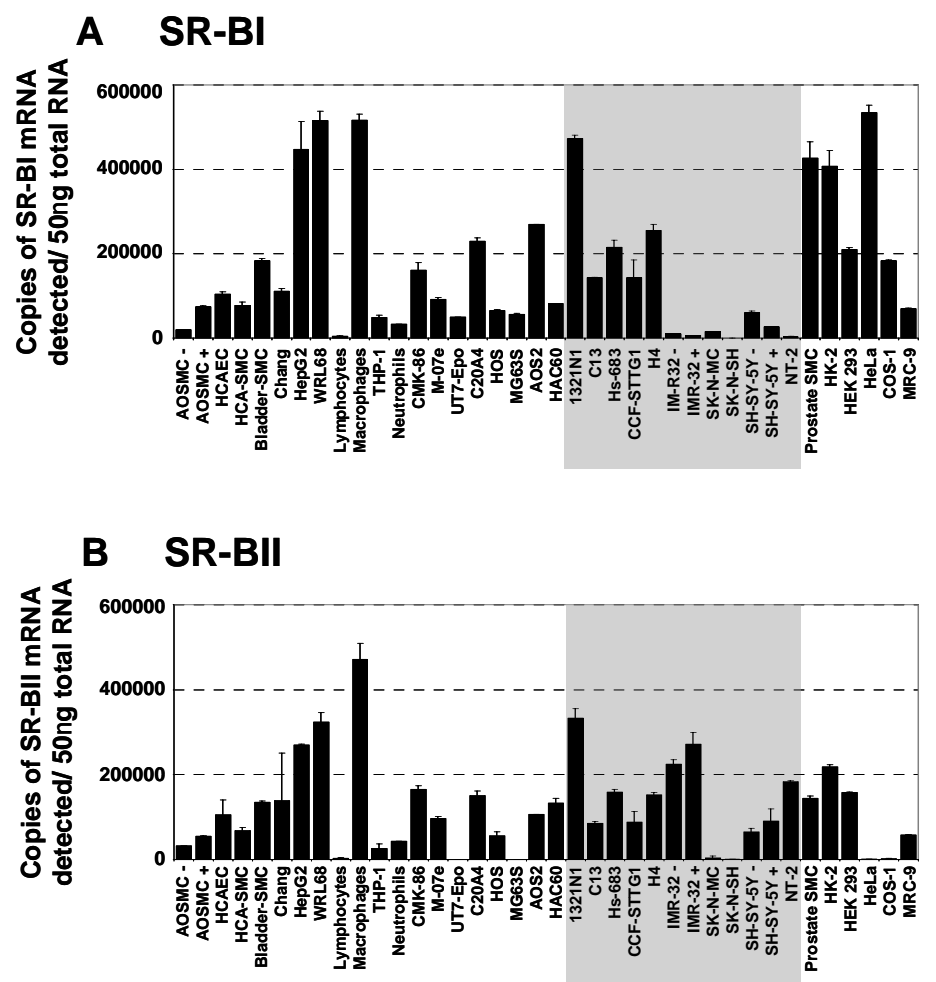

\section{SR-BII:SR-BI}

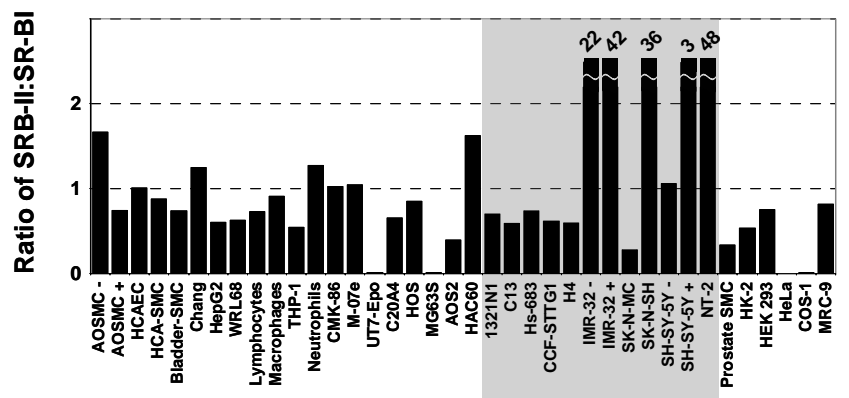

Fig. 3. Expression of HDL receptors by TaqCell plate assay. Levels of mRNA were measured in 38 human cell lines and primary cells for (A) SR-BI and (B) SR-BII. Data shown are the mean of a duplicate measurement ( \pm S.E.) of mRNA copy numbers in 50ng of reverse transcribed total RNA from the same batch of cells. (C) Calculated ratio of SR-BII:SR-BI mRNA expression. Brain-derived cell lines are highlighted; five lines gave ratios greater than 2.0 , in four cases markedly so, and the individual values for these are shown above the bars. 

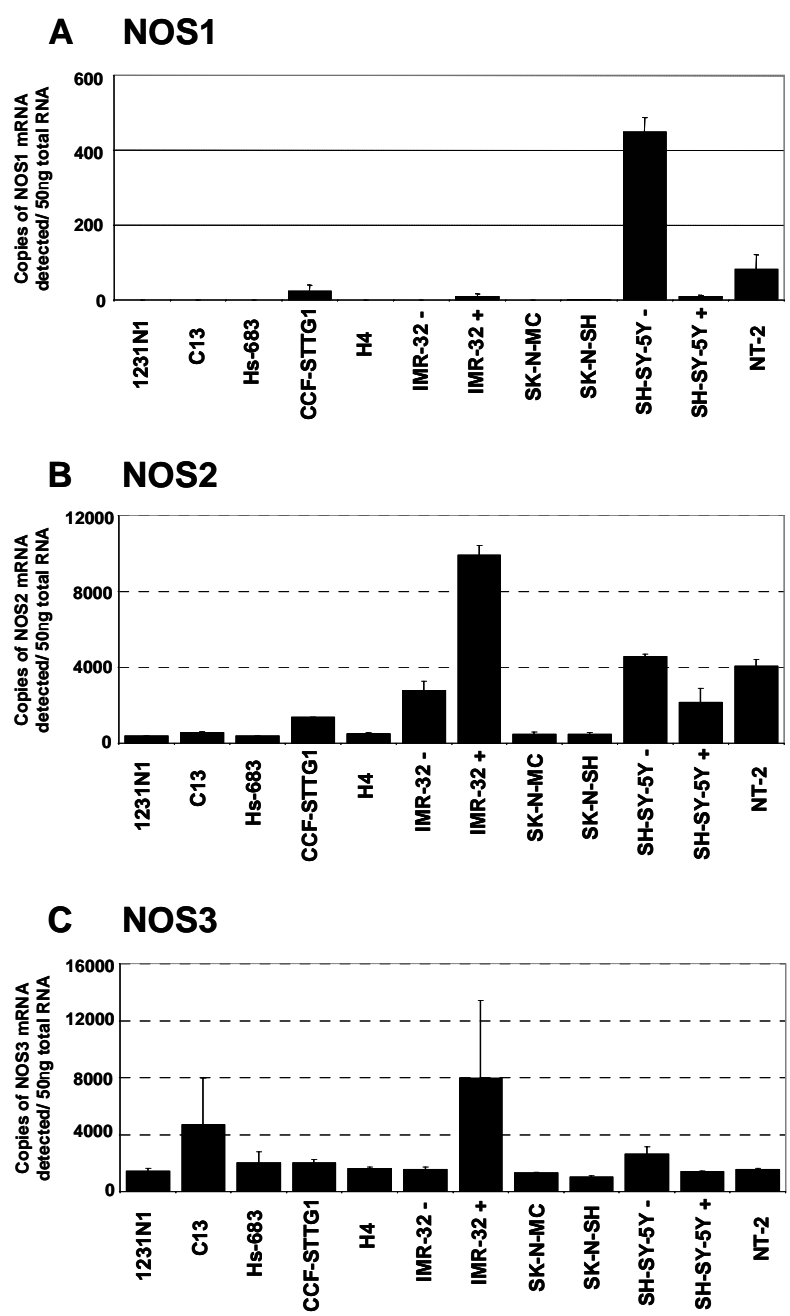

\section{PKB/Akt}

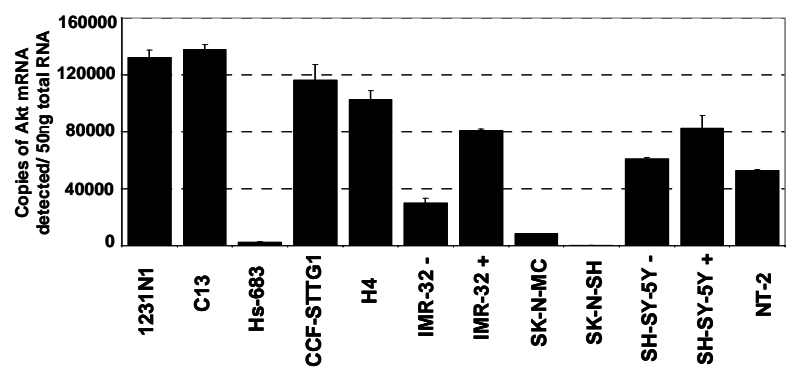

Fig. 4. Expression of NOS isoforms and PKB/Akt by TaqCell plate assay. Levels of mRNA were measured in 38 human cell lines and primary cells for (A) NOS1, (B) NOS2, (C) NOS3 and (D) the NOS3 regulatory kinase, PKB/Akt. Results are shown only for the brain-derived cells and are the mean of a duplicate measurement ( \pm S.E.) of mRNA copy numbers in 50ng of reverse transcribed total RNA from the same batch of cells. Note that the scaling on the Y-axis of each graph differs. 